\title{
Editorial
}

\section{In Memoriam: Hannes Haas}

Elisabeth Klaus ${ }^{1}$, Bradley S. Greenberg ${ }^{2}$ and António Vieira ${ }^{3}$

${ }^{1}$ Department of Communication, University of Salzburg, 5020 Salzburg, Austria; E-Mail: elisabeth.klaus@sbg.ac.at

${ }^{2}$ College of Communication Arts \& Sciences, Michigan State University, Michigan 48824, USA;

E-Mail: bradg@msu.edu

${ }^{3}$ Media and Communication, Cogitatio Press, Rua Fialho de Almeida 14, 2ㅇ Esq., 1070-129 Lisbon, Portugal;

E-Mail: antonio.vieira@cogitatiopress.com

\section{How to Cite this Article}

Klaus, E., Greenberg, B. S., \& Vieira, A. (2014). In Memoriam: Hannes Haas. Media and Communication, 2(1), 1.

\section{Copyrights}

(C) 2014 by the authors; licensee Cogitatio (Lisbon, Portugal). This article is licensed under a Creative Commons Attribution 4.0 International License (CC BY).

\section{Published by: \\ COGITATIO}

www.cogitatiopress.com

\section{About the Journal}

Media and Communication is an international open access journal dedicated to a wide variety of basic and applied research in communication and its related fields. It aims at providing a research forum on the social and cultural relevance of media and communication processes.

www.cogitatiopress.com/mediaandcommunication

\section{Editors-in-Chief}

Professor Bradley Greenberg, Departments of Communication and Telecommunication, Information Studies and Media, Michigan State University, USA

Professor Elisabeth Klaus, Department of Communication, University of Salzburg, Austria

\section{Managing Editor}

Mr. António Vieira, Media and Communication, Cogitatio Press, Portugal 
Editorial

\title{
In Memoriam: Hannes Haas
}

\author{
Elisabeth Klaus ${ }^{1}$, Bradley S. Greenberg ${ }^{2}$ and António Vieira ${ }^{3}$ \\ ${ }^{1}$ Department of Communication, University of Salzburg, 5020 Salzburg, Austria; \\ E-Mail: elisabeth.klaus@sbg.ac.at \\ ${ }^{2}$ College of Communication Arts \& Sciences, Michigan State University, Michigan 48824, USA; \\ E-Mail: bradg@msu.edu \\ ${ }^{3}$ Media and Communication, Cogitatio Press, Rua Fialho de Almeida 14, 2ㅇ Esq., 1070-129 Lisbon, Portugal; \\ E-Mail: antonio.vieira@cogitatiopress.com
}

Submitted: 24 March 2014 | Published: 9 April 2014

Issue

This editorial is part of the regular issue of Media and Communication, edited by Professor Bradley Greenberg (Michigan State University, USA) and Professor Elisabeth Klaus (University of Salzburg, Austria).

(C) 2014 by the authors; licensee Cogitatio (Lisbon, Portugal). This article is licensed under a Creative Commons Attribution 4.0 International License (CC BY).

\section{Hannes Haas (1957-2014)}

Regrettably, we announce the sudden death of Prof. Dr. Hannes Haas (aged 57), after a brief illness on March 20th, 2014. Hannes Haas, Editor-in-Chief of Media and Communication, was a Professor at the Institute of Communication Research at the University of Vienna and, alongside a throng of other roles, he served as head of the Institute from 2006-2010.

He was an unusually witty and committed teacher. He was well known in Austria, in the German-speaking countries, as well as worldwide for his scholarly work on media politics and journalism, his interest in the history of communication and his dedication to support quality journalism.

From the beginning he took a great interest in our journal and took major responsibility for the shape and content of its first issue. We lose an extremely knowledgeable, always reliable, friendly and supportive colleague.

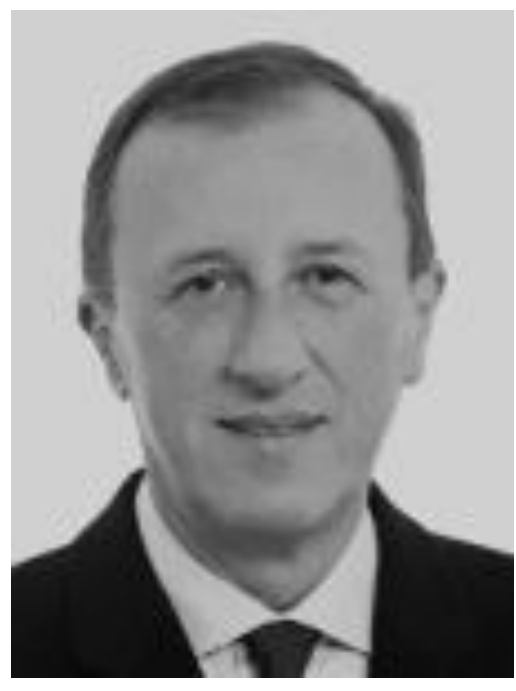

Hannes Haas 